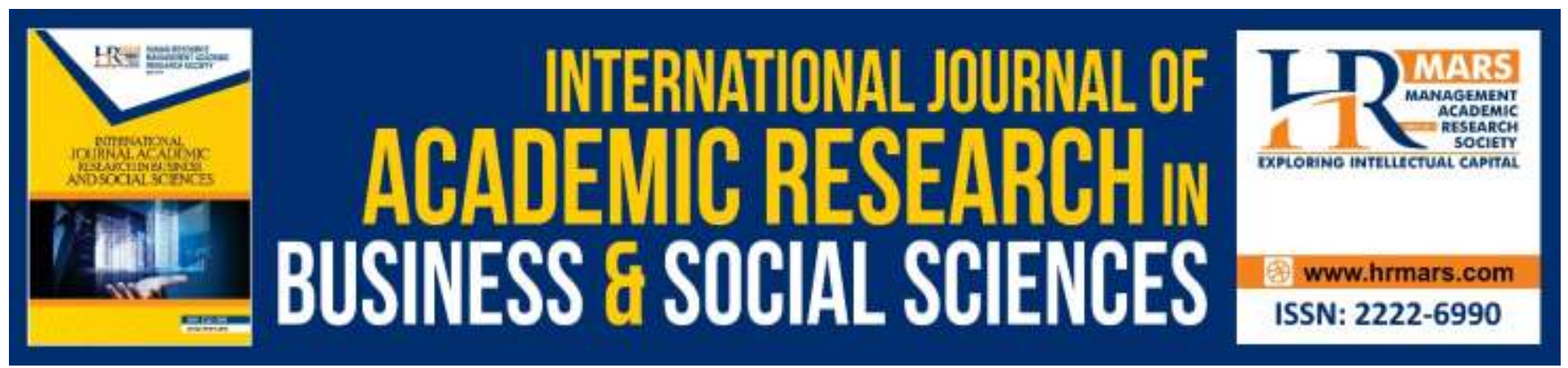

\title{
Roles of Facebook Usage among SMEs in Malaysia
}

Melissa Wee, Nurfatihah Yusrey, Mohd Zaki Sadik, Noraznira Abd Razak, Najihah Hanisah Marmaya and Heri Yanto

To Link this Article: http://dx.doi.org/10.6007/IJARBSS/v10-i3/7085

DOI:10.6007/IJARBSS/v10-i3/7085

Received: 05 February 2020, Revised: 20 February 2020, Accepted: 12 March 2020

Published Online: 31 March 2020

In-Text Citation: (Wee et al., 2020)

To Cite this Article: Wee, M., Yusrey, N., Sadik, M. Z., Razak, N. A., Marmaya, N. H., \& Yanto, H. (2020). Roles of Facebook Usage among SMEs in Malaysia. International Journal Academic Research in Business and Social Sciences, 10(3), 723-732.

\section{Copyright: (C) 2020 The Author(s)}

Published by Human Resource Management Academic Research Society (www.hrmars.com)

This article is published under the Creative Commons Attribution (CC BY 4.0) license. Anyone may reproduce, distribute, translate and create derivative works of this article (for both commercial and non-commercial purposes), subject to full attribution to the original publication and authors. The full terms of this license may be seen

at: http://creativecommons.org/licences/by/4.0/legalcode

Vol. 10, No. 3, 2020, Pg. 723 - 732

http://hrmars.com/index.php/pages/detail/IJARBSS

JOURNAL HOMEPAGE

Full Terms \& Conditions of access and use can be found at http://hrmars.com/index.php/pages/detail/publication-ethics 


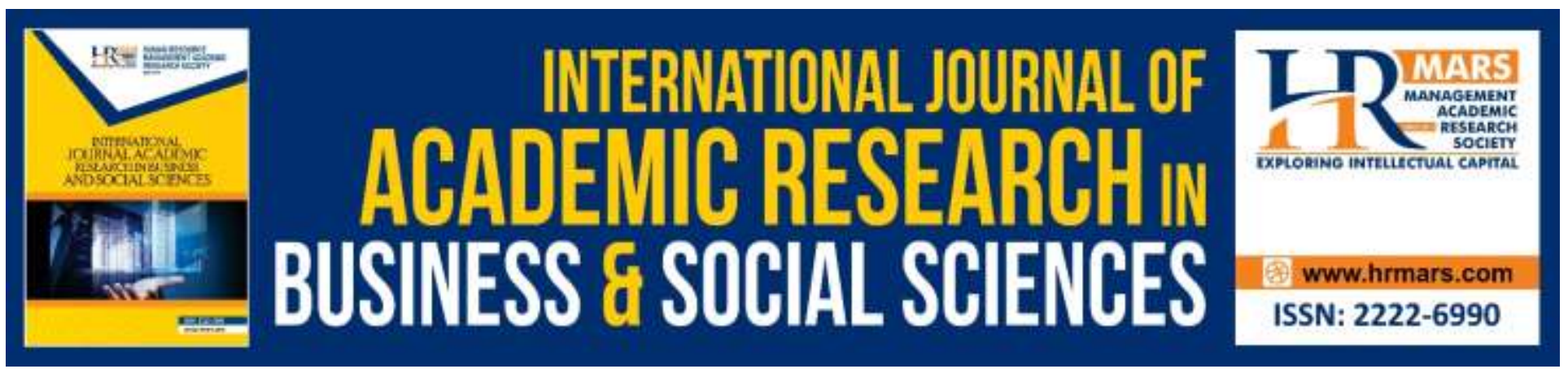

\title{
Roles of Facebook Usage among SMEs in Malaysia
}

\author{
Melissa Wee ${ }^{1}$, Nurfatihah Yusrey², Mohd Zaki Sadik³, Noraznira Abd \\ Razak $^{4}$, Najihah Hanisah Marmaya ${ }^{5}$ and Heri Yanto ${ }^{6}$ \\ Universiti Teknologi MARA Melaka, Malaysia ${ }^{1-5}$, Universitas Negeri Semarang, Semarang, Indonesia ${ }^{6}$
}

\begin{abstract}
The main objective of this study is to examine the roles of Facebook usage among SMEs in Malaysia. It has been argued that interactivity, cost effectiveness and compatibility are the factors of Facebook usage among SMEs in Malaysia. Since such usage among SMEs has increased continuously due to its features that are interactivity, cost effectiveness and compatibility, three hypotheses were postulated in this study. This study applies Statistical Package for Social Science (SPSS) method in analyzing the data that were distributed to 84 respondents through questionnaires. The findings of this study demonstrated that cost effectiveness and compatibility have positive relationship on Facebook usage among SMEs in Malaysia. Meanwhile, interactivity has no relationship on Facebook usage among SMEs in Malaysia. [The outcome of this study shall assist the government agencies to in facilitating contents during trainings and coaching session with the entrepreneurs.
\end{abstract}

Keywords: Facebook, Interactivity, Cost Effectiveness, Compatibility

\section{Introduction}

SMEs in Malaysia need to compete aggressively among countless competitors to achieve or sustain the market share in a particular industry or region. Nowadays, small and medium enterprises (SMEs) are undeniably playing a significant role in the economic development and the employment of a country. To be a high-income nation by 2020, the growth of SMEs need to be accelerated. According to SMEs Masterplan 2012 - 2020, 99.2 percent business establishment in Malaysia comes from SMEs. Based on the latest statistics, they contributed up to $32 \%$ of GDP, $59 \%$ of employment and $19 \%$ of exports.

According to WeAreSocial (2016), social media are now worldwide. As a matter of fact, about $85.4 \%$ of SMEs use social media to sell their products and services in order to achieve a larger market (SME Annual Report 2016/2017). Malaysia's government indicates that there is a slow growth in marketing among SMEs (SME Master Plan 2012 - 2020, p.51; SME Annual Report 2016/2017). Based on the past studies by Bhanot, (2012) most SMEs use social media like Facebook, for various functions including marketing, interaction, sales, and advertising. The use of social media is suitable for SMEs because it is low cost, mobility and only requires low IT skills (Breslauer et al., 2009; Toole, 2011; Durkin et al., 
INTERNATIONAL JOURNAL OF ACADEMIC RESEARCH IN BUSINESS AND SOCIAL SCIENCES Vol. 10, No. 3, March, 2020, E-ISSN: 2222-6990 @ 2020 HRMARS

2014). In Malaysia, there are 26,009,000 active Facebook users (Internet World Stats, 2019) and according to Derham et al., (2011) facebook has become a choice for endorsing business because it offers communications all around the world. Realizing such significant roles of SMEs in Malaysia, there is a need to find factors that can accelerate their social media roles in enhancing their business throughout the world and continuously contributing towards the growth of Malaysia.

\section{Literature Review}

Facebook Usage among SMEs

Social media has gotten close to our daily life and according to Kaplan and Haenlin (2010), social media refers to the Internet based application that allow users to exchange information. It is very convenient and offers low cost for businesses to engage with their customers (Fischer and Reuber, 2011). The adoption of technology has become popular in the workplace and firms can use it in a daily transaction flexibly at anytime and anywhere (Chen et al., 2008). In 2012, 500 companies rose in adopting social media (Okazaki and Taylor, 2013) and it showed that companies adopted social media for a long-term usage. Social media has become the most popular platform in businesses and acts as a communication tool between organizations and customers (Kumar et al., 2016). Studies by Bonsón \& Ratkai (2013) analyzed the utilization of Facebook in businesses and they all verbalized that it is beneficial for their businesses. This was supported by the past researcher Derham st al., (2011) in which Facebook was proven to be low cost and does not requires high level of IT skills and thus enable SMEs to use it conveniently in their transactions.

The reason why SMEs used Facebook is because this platform provides two-way communication between firms and customers (Meske \& Stieglitz, 2013). An organization uses Facebook as a platform of marketing communication and branding (Bruhn, M., Schoenmueller, V. and Schäfer, D.B., 2012). This was supported by Malhotra, A., Kubowicz Malhotra, C. and See, A. (2013) where Facebook is associated in engaging customers and building brand awareness. In a similar study by Edosomwan et al, (2011), the interaction between firms and customers, and engagement with customers had been developed through the adoption of technologies. Gazal et al., (2016) also agreed that social media is a platform where firms and customers interact with each other. As stated by Mangold \& Faulds (2009), social media such as Facebook can be also be stratified as part of the promotion mix whereby it helps a business owner to sell, advertise and market their product at a cheaper cost. Additionally, Bhanot, (2012) also found that Facebook as a platform where marketing, advertising, and cultural changes occur to achieve SMEs objectives. Past studies illustrated that roles such as interactivity (Lee \& Kozar, 2012), cost effectiveness (Chong \& Chan, 2012) and compatibility (Wang et al., 2010) influence Facebook usage.

Interactivity

Past researchers proposed three concepts of interactivity. Firstly, Newhagen, (2004) define interactivity as a perception-related variable where the experience of users was highlighted. Secondly, Kelleher, (2009) stated that interactivity is like a process-related variable where the process of information transfer between users takes place. Thirdly, interactivity can also be defined as a medium characteristic - interactivity happens due the features of technology per se. Interactivity is how well two or more parties communicate to each other, and the capability of organizations to 
INTERNATIONAL JOURNAL OF ACADEMIC RESEARCH IN BUSINESS AND SOCIAL SCIENCES Vol. 10, No. 3, March, 2020, E-ISSN: 2222-6990 (C) 2020 HRMARS

provide information regarded to their products or services to the customers (Goldfarb \& Tucker, 2011). Additionally, Kietzmann et al., (2012) demonstrated the rate of response between organizations and customers as the level of interactivity. Thus, the ability to communicate and engage with customers crucially leads to high level of interactivity (Elauf-Calderwood et al., 2005). Lee \& Kozar (2012) also mentioned that interactivity can be achieved when technological systems are designed substantially.

\section{Cost Effectiveness}

According to Ainin et al.. (2015), past researchers suggested social media implementation for its low cost yet high efficiency for marketers. By using social media, the cost of advertising and promotions are low (Dong-Hun, 2010) and the only cost for SMEs is the time to post on social media applications, considering the free sign-up (Zappe, 2010). Apart from that, social media is a platform where the business owners potentially reach their customers worldwide at low cost (Korda \& Itani, 2013). Furthermore, Chong \& Chan, (2012) stated that cost effectiveness is the main purpose of using new technology.

\section{Compatibility}

Compatibility were perceived as a major determinant in the use of innovation Wang et al., (2010) . Since the technology is compatible with work application systems, organizations might have an interest to adopt new technology (Low, Chen, \& Wu, 2011). As stated by Prem Kumar \& Robert, (1999), the changes from the adoption of technology in communication needs to be compatible with the firm's values and belief so that managers would heed the use new technological system in their organizations. In the past study, most researchers discovered that the use of technology have both, positive and negative results. A previous study on retail sector in South Africa, discovered the influence of compatibility towards radio frequency identification technology and found that it is important for an organization to develop a good IT infrastructure to successfully accommodate RFID systems (Brown and Russell, 2007).

\section{Research Model and Hypotheses}

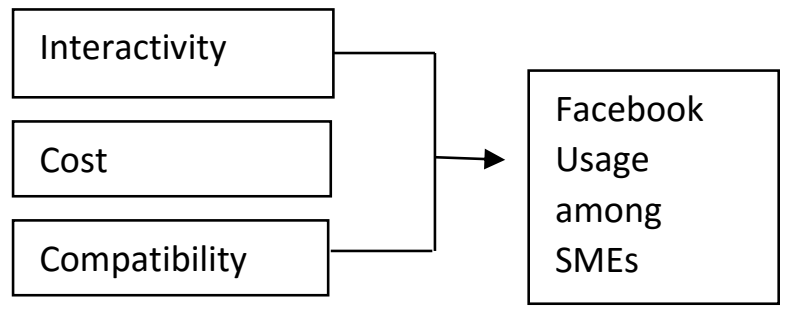

Figure 1: Theoretical Framework

\section{Facebook Usage and Interactivity}

As proposed by Rogers (2003), the interactive innovation of social media offers two-way communication, which helps to speed-up the adoption process because it attains a critical mass of users more quickly. Interactivity perceptions include consumer characteristics and situations. The 
INTERNATIONAL JOURNAL OF ACADEMIC RESEARCH IN BUSINESS AND SOCIAL SCIENCES

Vol. 10, No. 3, March, 2020, E-ISSN: 2222-6990 @ 2020 HRMARS

perceived values of interactivity lead a positive attitude toward innovation, thus influencing the adoption (Song \& Zinkhan, 2008). Based on previous studies, Lee \& Kozar, (2012) found that communication between human and technology is the key factor in designing the information systems. This was supported by Jiang \& Benbasat, (2007), whereby the design of information systems brings out interactivity that affect the response rate of users on the adoption of technologies. Facebook is a social media platform that offers interactions between firms and customers, different to the one-way communication via traditional media (Mayfield, 2008). Therefore, interactivity can give a strong influence on Facebook usage and thus developed the hypothesis below:

$\mathrm{H} 1$ : Interactivity has a positive relationship on Facebook usage among SMEs.

\section{Facebook Usage and Cost Effectiveness}

Previous study stressed the importance of cost in the use of technology (Ernst and Young, 2001). According to Alam and Noor (2009), there is a relationship between cost and utilization of technology that are direct and significant. Meanwhile Derham, R., Cragg, P. and Morrish, S. (2011) found some benefits for SMEs in using social media that includes low cost, low barriers to participation and low level of IT skills required. Furthermore Kaplan and Haenlein (2010), social media is cost-effective because organizations tend to use it to communicate directly with their customers for free. Therefore, the second hypothesis is as per below:

$\mathrm{H} 2$ : Cost Effectiveness has a positive relationship on Facebook usage among SMEs.

\section{Facebook Usage and Compatibility}

It was previously found that Facebook is compatible with a firm's existing IT infrastructure in both positive and negative results. Based on a study by Ramdani st al. (2009), compatibility has no significant effect in the adoption of technology among SMEs. In a similar study, Low et. Al (2011) also found that compatibility has no significant relationship on cloud computing function. However, some studies show that compatibility has a significant relationship on the use of technology innovations (Ainin et., 2015). Although some of the findings provided unpersuasive result, this study developed the third hypothesis as below:

H3: Compatibility has a positive relationship on Facebook usage among SMEs.

\section{Methodology}

Sample and data collection

The samples of this study are those SMEs who used Facebook in their businesses. A total of 84 respondents were asked to answer a questionnaire and two filter questions on whether they own a business with atleast 5 employees (to verify them as SMEs) and have a Facebook account for their company. This is to ensure that the respondents fulfilled the right criteria for this study.

\section{Respondents' Profile}

In terms of the demographic of the data are tabulated in Table 1, more than half of the survey respondents were from male population (61.9\%) and less than $39 \%$ are from the female population and majority of them aged between 42 to 49 years old $(29.8 \%)$ while minority is the respondents at the age of 18 until 25 years old (6\%). The rest of it were respondents of the age $26-33$ years old $(20.2 \%), 34-41$ years old $(27.4 \%), 50$ years old and above $(16.7 \%)$. All of the respondents were Malay 
INTERNATIONAL JOURNAL OF ACADEMIC RESEARCH IN BUSINESS AND SOCIAL SCIENCES

Vol. 10, No. 3, March, 2020, E-ISSN: 2222-6990 C 2020 HRMARS

(100\%). This is because all respondents are entrepreneurs under Majlis Amanah Rakyat (MARA) thus all respondents are bumiputera.

\section{Measures}

Data was collected using a structured questionnaire. The statements measuring these constructs were measured on a five-point Likert scale anchored with, " $1=$ not at all" to " $5=$ to a large extent" with "3=neutral." Regarding measures, the items for cost effectiveness were adapted from the work of Ainin et al. (2015). The items for interactivity were also adapted from literature (Ainin et al., 2015), while those for compatibility are adapted from Chong and Chan (2012). Facebook media usage items were adapted from McCann and Barlow (2015). The reliability test for all of the variables ranges were between 0.7 - 0.87 which were acceptable.

\section{Results}

In order to analyze the research model, this study employed the Statistical Package and Social Science (SPSS). SPSS analyzes data by using four types of analysis which are Descriptive statistic, Reliability and Multiple regression.

Assessment of Hypotheses

Table 1 Hypothesis Testing

\begin{tabular}{|l|l|c|c|c|c|c|}
\hline Hyp & Relationship & $\begin{array}{c}\text { Std } \\
\text { Beta }\end{array}$ & $\begin{array}{c}\text { Std } \\
\text { Error }\end{array}$ & $\begin{array}{c}\mathrm{t}- \\
\text { value }\end{array}$ & Sig & Decision \\
\hline H1 & $\begin{array}{l}\text { Facebook } \\
\text { Usage- } \\
\text { Interactivity }\end{array}$ & 0.073 & 0.096 & 0.762 & 0.448 & Supported \\
\hline H2 & $\begin{array}{l}\text { Facebook } \\
\text { Usage-Cost } \\
\text { Effectiveness }\end{array}$ & 0.307 & 0.120 & 2.546 & 0.013 & Supported \\
\hline H3 & $\begin{array}{l}\text { Facebook } \\
\text { Usage- } \\
\text { Compatibility }\end{array}$ & 0.215 & 0.101 & 2.126 & 0.037 & Supported \\
\hline
\end{tabular}

\section{Conclusion}

Based on the analysis it was revealed that interactivity has no significant relationship on Facebook usage among SMEs. This result was supported by the study from Kelleher, (2009) which defined interactivity as a process-related variable in which the level of interactivity could be different in new media and traditional media. For instance, Facebook page may have random messages in which it is a one-way communication that actually portrays low level of interactivity compared to the interaction through phone calls that could have higher level of interactivity. Hence, to perceive interactivity as synonym to social media rather than traditional media is not reliable. On the other hand, cost effectiveness has a positive relationship on Facebook usage among SMEs. This was supported by the past study done by Raphael Odoom, Thomas Anning-Dorson and George Acheampong, (2017) whereby cost effectiveness exhibited positive relationships on social media usage among SMEs. Moreover, Zappe (2010) clarified that cost effectiveness is the determinant of social media usage 
INTERNATIONAL JOURNAL OF ACADEMIC RESEARCH IN BUSINESS AND SOCIAL SCIENCES Vol. 10, No. 3, March, 2020, E-ISSN: 2222-6990 @ 2020 HRMARS

among SMEs as they can sign in the social networking sites for free and thus reducing cost of marketing. Moreover, the findings of this study shows that compatibility has a positive relationship with social media usage among SMEs and is supported with a similar result by Raphael Odoom, Thomas Anning-Dorson, George Acheampong, (2017) which stated that compatibility has a positive relationship with Facebook usage among SMEs. Therefore, it is crucial for an organization to have an innovative technology that is compatible with its beliefs and values. According to Derham., et al (2011), an organization can meet customer needs and preferences by focusing on their targeted customers through social media activities as they can personally and directly share any information, updates or even promotions related to their products or services. Additionally, this study also suggest that governments agencies in Malaysia, should provide trainings and coaching programs with for entrepreneurs to develop their skill on social media marketing techniques.

\section{References}

Abou-Shouk, M., Megicks, P., \& Lim, W. M. (2013). Perceived benefits and e-commerce adoption by SME travel agents in developing countries: Evidence from Egypt. Journal of Hospitality \& Tourism Research, 37(4), 490-515.

Ainin, S., Parveen, F., Moghavvemi, S., Jaafar, N. I., \& Mohd Shuib, N. L. (2015). Factors influencing the use of social media by SMEs and its performance outcomes. Industrial Management \& Data Systems, 115(3), 570-588.

Alam, S. S., \& Noor, M. K. M. (2009). ICT adoption in small and medium enterprises: An empirical evidence of service sectors in Malaysia. International Journal of Business and management, $4(2), 112-125$

Albright, S. C., Winston, W., \& Zappe, C. (2010). Data analysis and decision making. Cengage Learning.

Beloff, N., \& Pandya, P. (2010). Advertising models on social networks for SMEs-An advertising methodology. In 2010 International Conference on Internet Technology and Applications (pp. 1-6). IEEE.

Bonsón, E., \& Ratkai, M. (2013). A set of metrics to assess stakeholder engagement and social legitimacy on a corporate Facebook page. Online Information Review, 37(5), 787-803.

Brown, I., \& Russell, J. (2007). Radio frequency identification technology: An exploratory study on adoption in the South African retail sector. International journal of information management, 27(4), 250-265.

Bruhn, M., Schoenmueller, V., \& Schäfer, D. B. (2012). Are social media replacing traditional media in terms of brand equity creation?. Management Research Review, 35(9), 770-790.

Bucy, E. P., \& Tao, C. C. (2007). The mediated moderation model of interactivity. Media Psychology, 9(3), 647-672.

Burton-Jones, A., \& Gallivan, M. J. (2007). Toward a deeper understanding of system usage in organizations: A multilevel perspective. MIS quarterly, 31(4). 48.

Chong, A. Y. L., Chan, F. T., \& Ooi, K. B. (2012). Predicting consumer decisions to adopt mobile commerce: Cross country empirical examination between China and Malaysia. Decision Support Systems, 53(1), 34-43.

Cooper, R. B., \& Zmud, R. W. (1990). Information technology implementation research: a technological diffusion approach. Management science, 36(2), 123-139.

Derham, R., Cragg, P., \& Morrish, S. (2011). Creating Value: An SME And Social Media. PACIS, 53, 1-9. 
INTERNATIONAL JOURNAL OF ACADEMIC RESEARCH IN BUSINESS AND SOCIAL SCIENCES

Vol. 10, No. 3, March, 2020, E-ISSN: 2222-6990 @ 2020 HRMARS

Dong-Hun, L. (2010). Korean consumer \& society: growing popularity of social media and business strategy. Semi Quarterly, 3(4), 112.

Edosomwan, S., Prakasan, S. K., Kouame, D., Watson, J., \& Seymour, T. (2011). The history of social media and its impact on business. Journal of Applied Management and entrepreneurship, 16(3), 79-91.

Gefen, D., Karahanna, E., \& Straub, D. W. (2003). Trust and TAM in online shopping: an integrated model. MIS quarterly, 27(1), 51-90.

Goldfarb, A., \& Tucker, C. (2011). Online display advertising: Targeting and obtrusiveness. Marketing Science, 30(3), 389-404.

Ha, L., \& James, E. L. (1998). Interactivity reexamined: A baseline analysis of early business web sites. Journal of broadcasting \& electronic media, 42(4), 457-474.

Handayani, P. W., \& Lisdianingrum, W. (2011, December). Impact analysis on free online marketing using social network Facebook: Case study SMEs in Indonesia. In 2011 International Conference on Advanced Computer Science and Information Systems (pp. 171-176). IEEE.

Jiang, Z., \& Benbasat, I. (2007). Research note-investigating the influence of the functional mechanisms of online product presentations. Information Systems Research, 18(4), 454-470.

Kaplan, A. M., \& Haenlein, M. (2010). Users of the world, unite! The challenges and opportunities of Social Media. Business horizons, 53(1), 59-68. 49

Kelleher, T. (2009). Conversational voice, communicated commitment, and public relations outcomes in interactive online communication. Journal of communication, 59(1), 172-188.

Kietzmann, J. H., Silvestre, B. S., McCarthy, I. P., \& Pitt, L. F. (2012). Unpacking the social media phenomenon: towards a research agenda. Journal of public affairs, 12(2), 109-119.

Kirtiş, A. K., \& Karahan, F. (2011). To be or not to be in social media arena as the most costefficient marketing strategy after the global recession. Procedia-Social and Behavioral Sciences, 24, 260-268.

Knoll, J. (2016). Advertising in social media: a review of empirical evidence. International Journal of Advertising, 35(2), 266-300.

Korda, H., \& Itani, Z. (2013). Harnessing social media for health promotion and behavior change. Health promotion practice, 14(1), 15-23.

Lee, Y., \& Kozar, K. A. (2012). Understanding of website usability: Specifying and measuring constructs and their relationships. Decision support systems, 52(2), 450-463.

Lin, Kuan-Yu, and Hsi-Peng Lu. "Why people use social networking sites: An empirical study integrating network externalities and motivation theory." Computers in human behavior 27, no. 3 (2011): 1152-1161.

Liu, Y., \& Shrum, L. J. (2002). What is interactivity and is it always such a good thing? Implications of definition, person, and situation for the influence of interactivity on advertising effectiveness. Journal of advertising, 31(4), 53-64.

Low, C., Chen, Y., \& Wu, M. (2011). Understanding the roles of cloud computing adoption. Industrial management $\&$ data systems, 111(7), 1006-1023.

Mangold, W. G., \& Faulds, D. J. (2009). Social media: The new hybrid element of the promotion mix. Business horizons, 52(4), 357-365.

Markus, M. L. (1990). Theory of interactive media. Organizations and communication technology, 194-218. 
INTERNATIONAL JOURNAL OF ACADEMIC RESEARCH IN BUSINESS AND SOCIAL SCIENCES

Vol. 10, No. 3, March, 2020, E-ISSN: 2222-6990 @ 2020 HRMARS

Mayfield, A. (2008). What is social media. McCann, M., \& Barlow, A. (2015). Use and measurement of social media for SMEs. Journal of Small Business and Enterprise Development, 22(2), 273287. 50

McMillan, S. J., \& Hwang, J. S. (2002). Measures of perceived interactivity: An exploration of the role of direction of communication, user control, and time in shaping perceptions of interactivity. Journal of advertising, 31(3), 29-42.

Meske, C., \& Stieglitz, S. (2013, June). Adoption and use of social media in small and medium-sized enterprises. In working conference on practice-driven research on enterprise transformation (pp. 61-75). Springer, Berlin, Heidelberg.

Michaelidou, N., Siamagka, N. T., \& Christodoulides, G. (2011). Usage, barriers and measurement of social media marketing: An exploratory investigation of small and medium B2B brands. Industrial marketing management, 40(7), 1153-1159.

Newhagen, J. E. (2004). Interactivity, dynamic symbol processing, and the emergence of content in human communication. The information society, 20(5), 395-400.

Odoom, R., Anning-Dorson, T., \& Acheampong, G. (2017). Antecedents of social media usage and performance benefits in small-and medium-sized enterprises (SMEs). Journal of Enterprise Information Management, 30(3), 383-399.

Okazaki, S., \& Taylor, C. R. (2013). Social media and international advertising: theoretical challenges and future directions. International marketing review, 30(1), 56-71.

Parveen, F., Jaafar, N. I., \& Ainin, S. (2015). Social media usage and organizational performance: Reflections of Malaysian social media managers. Telematics and Informatics, 32(1), 67-78.

Premkumar, G., \& Roberts, M. (1999). Adoption of new information technologies in rural small businesses. Omega, 27(4), 467-484.

Rafaeli, S. (1988). From new media to communication. Sage annual review of communication research: Advancing communication science, 16, 110-134.

Rafaeli, S., \& Sudweeks, F. (1997). Networked interactivity. Journal of computer-mediated communication, 2(4), JCMC243.

Rogers, E. M. (1995). Diffusion of Innovations: modifications of a model for telecommunications. In Die diffusion von innovationen in der telekommunikation (pp. 25-38). Springer, Berlin, Heidelberg.

Rust, R. T., \& Varki, S. (1996). Rising from the ashes of advertising. Journal of Business Research, 37(3), 173-181. 51

Sarosa, S. (2012). Adoption of social media networks by Indonesian SME: A case study. Procedia Economics and Finance, 4, 244-254.

Sekaran, U., \& Bougie, R. (2013). Edisi 6. Research Methods for Business.

Alam, S. (2009). Adoption of internet in Malaysian SMEs. Journal of Small Business and Enterprise Development, 16(2), 240-255.

Sin Tan, K., Choy Chong, S., Lin, B., \& Cyril Eze, U. (2009). Internet-based ICT adoption: evidence from Malaysian SMEs. Industrial Management \& Data Systems, 109(2), 224-244.

Sohn, D. D., \& Leckenby, J. (2002). Social dimensions of interactive advertising. In PROCEEDINGS OF THE CONFERENCE-AMERICAN ACADEMY OF ADVERTISING (pp. 89-96). Pullman, WA; American Academy of Advertising; 1999. 
INTERNATIONAL JOURNAL OF ACADEMIC RESEARCH IN BUSINESS AND SOCIAL SCIENCES

Vol. 10, No. 3, March, 2020, E-ISSN: 2222-6990 @ 2020 HRMARS

Song, J. H., \& Zinkhan, G. M. (2008). Roles of perceived web site interactivity. Journal of marketing, 72(2), 99-113.

Stewart, D. W., \& Pavlou, P. A. (2002). From consumer response to active consumer: Measuring the effectiveness of interactive media. Journal of the Academy of Marketing Science, 30(4), 376396.

Teo, T. S., \& Pian, Y. (2003). A contingency perspective on Internet adoption and competitive advantage. European Journal of Information Systems, 12(2), 78-92.

Thiesse, F., Staake, T., Schmitt, P., \& Fleisch, E. (2011). The rise of the "next-generation bar code": an international RFID adoption study. Supply Chain Management: An International Journal, $16(5), 328-345$.

Tornatzky, L. G., \& Klein, K. J. (1982). Innovation characteristics and innovation adoptionimplementation: A meta-analysis of findings. IEEE Transactions on engineering management, (1), 28-45.

Wang, Y. M., Wang, Y. S., \& Yang, Y. F. (2010). Understanding the roles of RFID adoption in the manufacturing industry. Technological forecasting and social change, 77(5), 803-815.

Wang, Y. S., Li, H. T., Li, C. R., \& Zhang, D. Z. (2016). Factors affecting hotels' adoption of mobile reservation systems: A technology-organization-environment framework. Tourism Management, 53, 163-172. 52

Zolkepli, I. A., \& Kamarulzaman, Y. (2011). Understanding social media adoption: the role of perceived media needs and technology characteristics. World Journal of Social Sciences, 1(1), 188-199. 